\title{
Environmental Obligations in International Watercourse Law and South Asian Practice
}

\author{
Md. Nazrul Islam \\ Professor, Department of Law, University of Dhaka, Bangladesh
}

\section{INTRODUCTION}

International watercourses had long been seen as an economic resource ignoring environmental implications of their utilizations and resulting in conflict of interests between Basin States. Attempts to help resolve those conflicts by regulating their utilization and also for addressing environmental concerns, have given rise to a number of applicable legal principles over the last decades. In this regard, the 1997 UN Watercourse Convention remains as a landmark agreement, not only as the first global treaty on the subject, but also as an authentic evidence of customary rules governing utilization, development, and management of transboundary water. ${ }^{1}$

The convention entered into force on 17 August 2014 and so far it has counted a small number of ratifications. ${ }^{2}$ However, having its origin in the International Law Commission's (ILC) Draft Articles on the Law of the Non-navigational Uses of the International Watercourses, the Convention remains important also as a codification of international law potentially applicable even to the non-state parties. ${ }^{3}$

The period, after the Convention, has witnessed many interesting developments that in turn crystallized the rules and principles enshrined in the Convention. These developments are reflected in new treaties, regional conventions, and perhaps more notably in the proceedings of the watercourse disputes before the International Courts.

One important trend of such developments is the increasing focus on the environmental aspects of the utilization of transboundary watercourses. The global opening in 2016 of the 1992 UNECE Convention, ${ }^{4}$ which incorporates detailed environmental

1 Convention on the Law of the Non-navigational Uses of International Watercourses (adopted 21 May 1997, entered into force 17 August 2014) 2999 UNTS. It was adopted by a vote of 103 in favour including Bangladesh to 3 against with 27 abstentions including India and Pakistan. See UNGA Res 51/229 (21 May 1997) UN Doc A/RES/51/229 7-8.

2 The number of state parties to the Convention is 37 and signatories are 16, among them most are European and African states. See 'UNTC' (Treaties.un.org, 2021) $<$ https://treaties.un.org/Pages/ViewDetails.aspx?src=TREATY\&mtdsg_no=XXVII$12 \&$ chapter $=27 \&$ lang=en $>$ accessed 16 February 2021.

3 The ILC was established in 1946, under Article 13, Para. 1(a) of the UN Charter, to promote 'progressive development' and 'codification' of international law. On the International Law Commission, see, Ian Sinclair, The International Law Commission (Cambridge: Grotius Publications Limited 1987). For the ILC Draft Articles, see, UNGA 'Report of the International Law Commission on the work of its forty-sixth session' UN GAOR $49^{\text {th }}$ Session Supp No 10 UN Doc A/49/10 (1994) 218 [hereinafter 1994 ILC Report].

4 The title of the convention is 'Convention on the Protection and Use of Transboundary Watercourses 
provisions, the 2004 International Law Association Berlin Rules, the decisions of the International Court of Justice (ICJ) on a number of cases involving transboundary water, and the ever-increasing focus of environmental treaty regimes like the 1992 Biodiversity Convention on watercourse issues - all add to the strength of such an argument premised upon the environmental provisions of the 1997 Convention. ${ }^{5}$

On the basis of detailed analysis of these trends, this study argues that South Asia as a region has largely failed to conform with or sometimes even to discern the increasing focus of international watercourses law on environmental obligations. International watercourses in this region are still either governed by narrow understanding of economic interests or left to the unilateral control of the upstream countries. This argument is substantiated, among others, mostly by comparing the 1996 Ganges Water Treaty between Bangladesh and India to the contemporary developments of international watercourse law analyzed in the foregoing sections.

This study is important in order to highlight the lacking in sustainable management and utilization of international rivers among basin states of this region and suggest ways for developing a more efficient and sustainable regime for the benefit of the people of the concerned countries. It would make important contribution by suggesting the approach which should be adopted in future negotiation on the extension of the 1996 Treaty after its expiry in 2026 and in concluding agreements on other shared rivers.

\section{THE 1997 WATERCOURSE CONVENTION}

On 21 May 1997, the General Assembly adopted the convention on the basis of the draft articles prepared by the ILC and elaborated by the United Nations General Assembly (UNGA) sixth committee working group. ${ }^{6}$ The Convention entitled 'Convention on the Law of the Non-navigational Uses of International Watercourses' [hereinafter the Watercourse Convention or the 1997 Convention] entered into force in 2014.

The Convention sets forth the general principles and rules governing non-navigational uses of international watercourses in the absence of specific agreements among the States concerned and provides guidelines for the negotiation of future agreements. ${ }^{7}$ It

and International Lakes'. It was adopted by the members of United Nations Economic Commission for Europe in 1992. See, Convention on the Protection and Use of Transboundary Watercourses and International Lakes (adopted 17 March 1992, entered into force 6 October 1996) 1936 UNTS 269 [Hereinafter UNECE Convention].

5 See for example, Sabine Brels, David Coates and Flavia Loures, 'Transboundary Water Resources Management: The Role of International Watercourse Agreements in Implementation of the CBD' (CBD Technical Series no. 40, Montreal: CBD Secretariat 2008) <https://www.cbd.int/doc/publications/cbd-ts-40-en.pdf> accessed 13 December 2020.

6 The initiative for the 1997 Watercourse Convention was undertaken by the United Nations General Assembly (UNGA). In a resolution of 8 December 1970, the UNGA recommended the International Law Commission (ILC) to take up a study of the law of the non-navigational uses of international watercourses with a view to its 'progressive development and codification'. See, UNGA Res 2669 (XXV) (1970) UN Doc A/CN.4/244/Rev. 1, para1. For the text of the draft articles adopted in 1994 and the commentaries of the ILC to these articles, see, UNGA (n 3) 197-327.

7 UNGA Press Release, 'General Assembly adopted Convention on the Law of Non-navigational Uses 
consists of seven parts containing 37 Articles: Introduction; General Principles; Planned Measures; Protection Preservation and Management; Harmful Conditions and Emergency Situations; Miscellaneous Provisions and Final Clauses. ${ }^{8}$ An annex to the Convention sets forth the procedures which could be used in the event the parties to a dispute agree to submit it to arbitration.

The following sections identify, analyze and highlight the environmental obligations specifically or impliedly addressed in various provisions of the Convention. Among these provisions, the 'General Principles' laid down in Part II of the Convention and the procedural principles incorporated in Part III refer to environmental obligations as their inseparable component. On the other hand, Part V of the convention elaborates the environmental provisions of the Convention and relates them to other substantive obligations defined in the convention. In the course of discussing the above principles, this study takes into account the relevant 'Statements of Understanding' of the Sixth Committee Working Group ${ }^{9}$ and the commentaries of ILC to the draft articles it adopted in $1994 .^{10}$

\section{A. Environmental focus in substantive principles}

The 1997 convention centers on two important substantive principles, namely, equitable utilization and no-harm principles and explains their relationship. Unlike the previous codifications such as the Helsinki Rule of $1966,{ }^{11}$ it defines those principles in a way which represents an integration of environmental concerns and economic

of International Watercourses' (21 May 1997) GA/9248.

8 The introduction part of the Convention explains the scope of the Convention and defines key terms. Article 1 provides that this Convention applies to non-navigational uses of international watercourses and consequently also to those navigational uses which affect non-navigational uses of international watercourses. Article 2 defines international watercourse as a watercourse parts of which are situated in different States and provides that watercourse means a system of surface waters and ground waters constituting by virtue of their physical relationship a unitary whole and normally flowing into a common terminus. It also provides that Watercourse State means a State in whose territory part of an international watercourse is situated.

9 These Statements were included in the Report of the Sixth Committee Working Group to the General Assembly. McCaffrey and Sinjela described these Statements as travaux preparatoires of the 1997 Convention. See, Stephen C. McCaffrey and MpaziSinjela, 'The 1997 United Nations Convention on international watercourses' (1998) 92 AJIL 102. For the 'Statements of understanding' with the text of the Convention see, UNGA, 'Report of the Sixth Committee convening as the Working Group of the Whole' (11 April 1997) UN Doc A/51/869 <https://www.un.org/ga/search/view_doc.asp? symbol=A/51/869> accessed 16 February, 2020.

10 These commentaries appear in the 1994 ILC Report, UNGA (n 3). The legitimacy of invoking ILC commentaries is established by the Sixth Committee Working Group during its elaboration of the Convention. The Sixth Committee Working Group (ibid para 8) noted that: "[T]hroughout the elaboration of the draft Convention, reference had been made to the commentaries to the draft articles prepared by the International Law Commission to clarify the contents of the articles".

11 The Helsinki Rules were based on reports of the River Committee, established in 1954 by the International Law Association, a highly reputed international non-governmental organization. The Committee submitted its final report to the Helsinki conference of ILA in 1966 and the articles included in the report were adopted as 'Helsinki Rules' by the ILA conference. See, Bourne, 'The International Law Association's contribution to international water resources Law' (1996) 36 Natural Resources Journal 155-213.

Page | 134 
interests of the watercourse states. Further, their inclusion in the convention as general principle suggests that those environmental concerns must not be overlooked in utilization and development of international watercourses.

\section{Equitable utilization}

Article 5(1) of the convention requires a Watercourse State to exercise its rights to utilize an international watercourse in an 'equitable and reasonable manner'. The objectives are to attain 'optimal and sustainable utilization', to take into account the interests of other Watercourse States concerned and at the same time, to ensure 'adequate protection of the watercourse'. ${ }^{12}$ This emphasis on 'sustainable' utilization and adequate 'protection' of the watercourse is a comparatively new development and it underlines a duty to protect the ecological features and functions of the watercourse in planning and executing its development, management and utilization.

Article 5(2) introduces a complementary principle of equitable participation of Watercourse States in 'the use, development and protection' of an international watercourse. As ILC commentary to this Article explains, equitable participation is linked to Article 8 which defines the principle of co-operation in more general terms, necessitating compliance with procedural duties. ${ }^{13}$ This requirement is environment friendly as it underscores the necessity of involving all the watercourse states without which the indivisible ecological character of the watercourse cannot be safeguarded.

Article 6(1) contains a non-exhaustive list of factors to be taken into account in determining whether a utilization of international watercourse is equitable and reasonable. These factors include environmental issues such as conservation and protection of the water resources along with other traditional and long-established factors: the natural condition of the watercourse, social and economic needs of the Watercourse States, dependent population, effect of a use of the watercourse on other Watercourse States, existing uses of the watercourse and available alternatives. The incorporation of conservational aspects of the watercourse and also of the "potential uses' along with existing uses in Article 6(1) corresponds with the provisions of Article 5 on sustainable use and adequate protection of watercourse. This enjoins the watercourse States with greater responsibility which the Working Group considered to be appropriate in view of the recent development of the international environmental law (IEL). ${ }^{14}$

\section{No- harm principle}

As observed by the ILC, “Article 5 [concerning principle of equitable utilization] alone

\footnotetext{
Para 2 of the Commentary to Article 5 of 1994 ILC Report. See, UNGA (n 3) 220.

Para 6 of the Commentary to Article 5 of 1994 ILC Report. Ibid.

14 See, UNGA Summary Record of $24^{\text {th }}$ Meeting (17 September 1996) GAOR 51 $1^{\text {st }}$ Session Sixth Committee UN Docs. A/C.6/51/SR.15-20 4, para 14. The Chairman of the Drafting Committee of the Working Group recalled that inclusion of the principle of sustainable development and protection of ecosystem in the Convention was proposed 'in order to bring the draft articles more fully into line with contemporary international environmental law'.
} 
did not provide sufficient guidance for States where harm was a factor". ${ }^{15}$ The Commission found enough legal materials to formulate a principle concerning harm, although the question of its stringency and its relationship with equitable utilization formed lengthy debate both in the ILC and in the Sixth Committee of the General Assembly. ${ }^{16}$

Article 7 obligation comprises both pre-harm obligation of taking preventive measures for avoiding causing of 'significant harm' to other watercourse States ${ }^{17}$ and post-harm obligation of consulting the affected State in order to mitigate such harm and pay compensation in appropriate cases.

The whole process indicates that Article 7, although basically sets forth or entails obligations of conduct, it also reflects obligations of result. A watercourse State first has to take preventive measures and thereafter, if harm is caused, has to consult with the affected State for an equitable resolution for eliminating or mitigating harm and for compensating in appropriate case and lastly if the consultation fails, has to enter into dispute settlement procedures for such resolution.

It should be pointed out here that the above explained no-harm principle covers environmental harms as well. The ILC, while formulating this Article, defined harm as a detrimental impact of some consequence upon sectors which include environment in the affected State along with its public health, industry, property or agriculture. ${ }^{18}$ As McCaffrey, the longest serving rapporteur of the ILC on the subject, explained, such harm "may take the form of a diminution in quantity of water, due, for example, to new upstream works or pumping of groundwater" and it could also result from factors such as pollution, obstruction of fish migration, increased siltation due to upstream deforestation, negative impacts on the riverine ecosystem due to conduct in another riparian state etc. ${ }^{19}$

It may also be argued that some types of environmental harm would not only be inconsistent with Article 7 on no-harm, it would also violate the principle on equitable

15 Para 2 of the commentary to Article 7 of the 1994 ILC Report. See, UNGA (n 3) 236.

16 See Nussbaum, 'Report of the working group to elaborate a convention on international watercourses' (1997) 6 RECIEL 49-50. Stephen C. McCaffrey and MpaziSinjela (n 9) 101. Bourne, 'The International Law Commission's draft articles on the law of international watercourses, principles and planned measures' (1992) 3 Colorado JIELP 73-82.

17 The expression 'significant harm' was preferred by the ILC in its draft articles of 1994, although in the 1991 draft articles, it was 'appreciable harm'. The Special Rapporteur of the ILC, Mr. Rosenstock, while sitting as an expert consultant during the elaboration of the Watercourse Convention by the Working Group, explained that the change from appreciable to significant was made only to avoid the possibility that in addition to substantial harm, trivial harms could also be measured by increased scientific and technological capacities and therefore may be confused with the term 'appreciable' meaning capable of being measured. He concluded: "As the Commission's records made abundantly clear, the change from 'appreciable' to 'significant' had not been intended to alter the thresholds, but to avoid a circumstance in which the threshold could be lowered to a clearly de minis level". See, UNGA Summary Record of the $16^{\text {th }}$ Meeting GAOR 51st Session Sixth Committee Para. 35.

18 (1988) II (2) Yearbook of International Law Commission 36, para 188.

19 Stephen C. McCaffrey, The Law of International Watercourses, (3rd edn, Oxford University Press 2019) 470.

Page | 136 
utilization. The ILC's commentary to Article 7 provides: "A use which causes significant harm to human health and safety is understood to be inherently inequitable and unreasonable." Basing on this, McCaffrey commented, "[s]ignificant pollution harm to a state or its environment would usually entail significant harm to human health and safety, and would therefore be "inherently inequitable and unreasonable." 20

\section{Other General Principles}

The Convention, in its Articles 8 to 10, spells out other general principles which facilitate implementation of equitable utilization. Under Article 8, watercourse States are required to co-operate each other on the basis of 'sovereign equality, territorial integrity, mutual benefit and good faith' which are defined as the 'most fundamental principles' in the relevant commentary of the ILC. ${ }^{21}$ Article 9 provides for regular exchange of data and information on the condition of a watercourse. ${ }^{22}$ The purpose is to ensure that 'the Watercourse States will have the facts necessary to enable them to comply with their obligations under Article 5, 6, and 7'.23 Article 10 requires watercourse States to resolve conflicts between various types of uses in the light of the provisions of Article 5 to 7 , giving special regard to 'vital human needs' ${ }^{24}$ These general principles suggest an inseparable relationship between the principles of noharm, equitable utilization and cooperation. ${ }^{25}$

Further, as these general principles are to ensure compliance with Article 5-7 and as these Articles entail obligations including that of not causing environmental harm, these general principles could serve to facilitate compliance with environmental obligations.

\section{B. Procedural obligation includes exchange of environmental information}

Planned measures are defined in the 1997 Convention as 'new projects or programmes of major or minor nature' as well as 'changes in existing uses of an international watercourse'. ${ }^{26}$ The Convention incorporates a comprehensive set of procedural obligations concerning planned measures. These include exchange of information, consultation and negotiation on the 'possible effects' of planned measures on the condition of an international watercourse. These obligations are unconditional, and

\section{Ibid 512.}

21 Para 2 of the commentary to Article 8 of the 1994 ILC Report. See, UNGA (n 3) 245.

22 Para 1 of the commentary to Article 9 of the 1994 ILC Report. Ibid 250.

23 Para 2 of the commentary to Article 9 of the 1994 ILC Report. Ibid.

24 Para 4 of the commentary to Article 10 of the 1994 ILC Report. Ibid 257. It defines 'vital human needs' as 'an accentuated form' of the factor contained in Article 6, Para 1(b) which refers to social and economic needs of the watercourse States concerned. Vital human needs thus indicate uses of water to sustain human life, like drinking water and water required for the production of food to prevent starvation.

25 Analyzing the way these principles have been addressed in the 1997 and 1992 Convention, Atilla concludes that they have a 'mutually reinforcing legal relationship'. He also argues that these two principles produce 'a framework for prevention, management and settlement that facilitates cooperative scenarios'. See, Attila M. Tanzi, 'The inter-relationship between no harm, equitable and reasonable utilisation and cooperation under international water law' (2020) 20 International Environmental Agreements: Politics, Law and Economics 619-629. 
irrespective of actual effects of planned measures. ${ }^{27}$

The first procedural duty is notification (Article 12) of planned measures which 'may have a significant adverse effect' upon other Watercourse States. Such notification is required to be accompanied by 'available technical data and information including the result of any environmental impact assessment'.

Article 16 and 17 of the Convention deal with obligations those follow notification of planned measures. Accordingly, if the notified State communicates to the notifying State that the planned measures would be inconsistent with the provisions of Article 5 or 7, then both States have to begin consultation and, if necessary, negotiation with a view to arriving at 'an equitable resolution of the situation'. The above principles had been addressed in the ILC as 'indispensable adjunct to the general principle of equitable utilization' ${ }^{28}$ These principles basically lay down obligations proceeding to actual dispute. These principles and Article 33 (concerning dispute resolution) appear to form an integral procedural framework for implementing the substantive obligation in relation to the utilization of international watercourses.

Article 33 contains dispute settlements procedures in order to respond to the 'complexity' and 'inherent vagueness' of the criteria to be applied for equitable utilization of international watercourses. ${ }^{29}$ Dispute settlement procedures can be invoked gradually: first bilateral methods thereafter optional methods of third-party settlement, and lastly, if optional methods are not agreed, a mandatory Fact-finding Commission which can be established by any of the parties to a dispute. ${ }^{30}$ The purpose of such Fact-finding Commission would be to facilitate resolution of a dispute through the 'objective knowledge of the facts' ${ }^{31}$ Article 33 puts noticeable emphasis on Factfinding Commission by making detailed provisions explaining the procedures concerning appointment and functions of such Commission.

It should be noted here that facts which are central in complying with the obligations under the 1997 Convention include facts relating to environmental impact of any planned measure. Article 12 specifically mentions such requirement and it was later reinforced in the decisions of international court. For example, in the Pulp Mill case, the ICJ opined, "it may now be considered a requirement under general international law to undertake an environmental impact assessment where there is a risk that the proposed industrial activity may have a significant adverse impact in a transboundary context, in particular, on a shared resource." ${ }^{32}$

\section{Protection and preservation of the watercourse}

\footnotetext{
Para 3 of the commentary to Article 11 of the 1994 ILC Report. Ibid 259, 260.

28 Stephen C. McCaffrey, 'Second report' (1986) II(2) YILC 139, para 188. For detail, see Stephen C. McCaffrey, 'Third Report' (1987) II(1) YILC 22-23, paras. 32-35.

29 Para. 21 of the Commentary to Article 7 of the 1994 ILC Report.UNGA (n 3) 244.

30 Clause 3, 4 and 5 of Article 33.

31 Para 4, Commentary to Article 33 of the 1994 ILC Report.UNGA (n 3$) 324$.

32 Pulp Mills on the River Uruguay (Argentina v. Uruguay) (Judgment) ICJ Reports 2010 83, para 204 <https://www.icj-cij.org/public/files/case-related/135/135-20100420-JUD-01-00-EN.pdf> accessed 16 February 2021.
}

Page | 138 
The 1997 Convention lays stress on the needs for sustainable use of international watercourses and its adequate protection in a number of articles particularly in Article 5-7. Further, it devotes a whole Part (Part IV) to elaborate the principles concerning protection, preservation and management of the international watercourses.

Article 20 of Part IV of the 1997 Convention requires watercourses states to act individually and in appropriate cases jointly to protect and preserve the ecosystems of international watercourses. ${ }^{33}$ The obligation to protect the watercourse ecosystem is a specific application of the requirement contained in Article 5 that watercourse states are to use and develop an international watercourse in a manner that is consistent with adequate protection thereof. In essence, it requires the watercourse states to shield the ecosystem of international watercourses from harm or damage. ${ }^{34}$

While commenting on this article, McCaffrey observed that "Together with the pronouncements of the ICJ in Gabčíkovo-Nagymaros, Pulp Mills, the Road case, and the Nuclear Weapons Advisory Opinion, it shows that international law is adapting to take into account advances in scientific understanding of natural systems." 35

Article 21 spells out a specific obligation of protection of international watercourses by requiring the watercourse states to "prevent, reduce and control the pollution of an international watercourse that may cause significant harm to other watercourse States or to their environment, including harm to human health or safety, to the use of the waters for any beneficial purpose or to the living resources of the watercourse."

Article 23 provides for protection and preservation of the marine environment, including estuaries, taking into account generally accepted international rules and standards. Article 24 and 25 provide for mutual cooperation respectively for management and regulation of international watercourses. Article 27 requires prevention and mitigation of harmful conditions related to international watercourses that may have adverse impact on other watercourse states.

Further, these articles can be interpreted to address much wider normative expectations. For example, the obligation of causing no significant environmental harm under Article 21 may include regulating activities which reduce downstream flow and thus help saline intrusion from the sea. ${ }^{36}$ Likewise, the obligation of prevention and mitigation of harmful conditions under Article 27 may include environmental impacts of human activities.

33 As Commentary to Article 20 of the 1994 ILC Report.UNGA (n 3) 280. It provides that "[T]he term ecosystem means an ecological unit comprising living and non-living components that are interdependent and function as a community". Ibid 282.

Stephen C. McCaffrey (n 19) 517.

Owen McIntyre, Environmental Protection of International Watercourses under International Law (Aldershot: Ashgate 2007) 117. 


\section{Customary rules concerning environmental obligations}

Being based on the draft articles of the International Law Commission, the 1997 Watercourse Convention comprises 'codification (existing rules) and progressive development (developing principles)' of the laws of non-navigational uses of international watercourses. ${ }^{37} \mathrm{The}$ ICJ in a number of cases recognized this dual utility of multilateral conventions. ${ }^{38}$ In its commentaries to the draft articles, the ILC itself made valuable indication to the customary international law status of various principles of the Convention. For example, the ILC described the principle of equitable utilization as a 'well-established rule, ${ }^{39}$ and the no-harm principle as a 'general obligation' of watercourse states, although the UN Sixth Committee Working Group, while negotiating the Convention, experienced lack on unanimity on the relation between the two. ${ }^{40}$

While completing the final draft in 1994, the ILC noted the existence of relatively few examples of state practice on some issues. For example, while it strongly endorsed most of the environmental and procedural obligations, such as protecting the watercourse ecosystem, not causing pollution, and negotiating in good faith, it also noted that mandatory fact-finding commission has received only 'considerable attention by States $^{41}$ and the obligation of protecting marine environment from watercourse pollution is 'recognized only relatively recently'. ${ }^{42}$

Nevertheless, the ILC's suggestion that most of the principles enshrined in the 1997 Convention are either established or emerging principles of customary laws, is substantiated by the way the Convention has influenced subsequent watercourse agreements including those in the Asian and African regions. ${ }^{43}$

The above provisions, if read with other contemporary codifications discussed below and also with the near-universally accepted multilateral environmental agreements such as those on biodiversity and climate change, suggest that disregarding environmental issues in any planned utilization of an international watercourse would be a clear deviation from the applicable global norms. ${ }^{44}$

37 Statute of the International Law Commission,UNGA Res. 174 (II) 2 UN GAOR (Res) UN Doc. A/519 (1948) art 1 and 15.

38 For example, Military and Paramilitary Activities in and Against Nicaragua (Nicaragua v United States) (Merits) [1986] ICJ Rep 14; North Sea Continental Shelf Cases (Federal Republic of Germany v. Denmark; Federal Republic of Germany v. Netherlands) [1969] ICJ Rep 3, 37-41.

39 UNGA (n 3) 218-331.

40 UNGA Res 51/229 (n 1) 1-12.

41 Para 4 of the Commentary to Article 33 of the 1994 ILC Report.UNGA (n 3) 324.

42 Para 1 of the Commentary to Article 23 of the 1994 ILC Report.UNGA (n 3) 285.

43 For resources on global influence and relevance of the Convention, see, 'Global Relevance - UN Watercourses Convention' (Unwatercoursesconvention.org, 2021) <https://www.unwatercoursesconvention.org/global-relevance/> accessed 16 February 2021. See also, Flavia Rocha Loures and AlistarRieu Clarke (eds), The UN Watercourses Convention in Force, Strengthening International Law for Transboundary Water Management (London: Routledge 2017).

44 Md Nazrul Islam, 'Environmental Impacts of the Ganges Water Diversion and Its International Legal Aspects' in M MonirulQader Mirza (ed), The Ganges Water Diversion: Environmental Effects and Implications (Dordrecht: Kluwer 2004) 218-220.

Page | 140 


\section{1992 UNECE CONVENTION AND ITS GLOBAL OPENING IN 2016}

The integration of environmental issues in the watercourses law had been cemented through the adoption of the 1992 UNECE Convention on the Protection and Use of Transboundary Watercourses and International Lakes and its global opening in $2016 .{ }^{45}$ This global opening signaled the realization of state parties to the UNECE Convention that with more emphasis on environmental and institutional aspects, the Convention should be expanded to countries outside the UNECE region. ${ }^{46}$ Also, the joining of two African Countries, Chad and Senegal, to this Convention in 2018 and the willingness of few more to join indicate the increasingly broader acceptance of the Convention. ${ }^{47}$

The 1992 ECE Convention is a strong endorsement against significant adverse effect of watercourse utilization. Such effects include "effects on human health and safety, flora, fauna, soil, air, water, climate, landscape and historical monuments or other physical structures or the interaction among these factors". ${ }^{48}$

The 1992 Convention $^{49}$ provides for integrated water resources management through the basin approach involving all the basin states of a shared watercourse ${ }^{50}$ Compared to the 1997 Convention, the central focus of the 1992 Convention is ecologically sound and rational water management, conservation of water resources and environmental protection. ${ }^{51}$ It has therefore established more detailed and specific duties for delimitation or elimination of environmental harms in a number of ways.

First: the 1992 Convention requires pollution prevention, control and reduction at source, prior licensing of waste-water discharges, application of biological treatment or equivalent processes to municipal waste-water to enhance national systems for water

45 The Convention was originally negotiated as a regional instrument for the member states of the UN Economic Commission for Europe. Amendments in 2003 to Articles 25 and 26 of the Convention allowed all UN Member States to accede to the Convention as from 1 March 2016.

46 See UNESC 'Draft strategy for the implementation of the Convention at the global level' (30 July 2018) UN

Doc ECE/MP/WAT/2018/6<https://www.unece.org/fileadmin/DAM/env/documents/2018/WAT/10Oct_1 0-12_8thMOP/Official_docs/ECE_MP.WAT_2018_6_ENG.pdf> accessed 16 February 2021.

During the Meeting of the Parties in 2018, around 20 countries from Africa, Latin America and Asia announced their interest to accede to the 1992 Convention, see,'The Water Convention and The Protocol on Water and Health | UNECE' (Unece.org, 2021) <https://www.unece.org/env/water.html> accessed 16 February 2021.

49 It entered into force in 1996 and as of August 2019, it counts 43 Parties - almost all countries sharing transboundary waters in the region of the United Nations Economic Commission for Europe (UNECE).

50 As the UNECE observed, the 1992 Framework Convention has contributed to or served as a model for the transboundary agreements on the Chu-Talas, Danube, Dniester, Drin, Rhine and Sava Rivers, as well as agreements on the Belarus-Russian, Belarus-Ukrainian, Estonian-Russian, Kazakh-Russian, Mongolian-Russian, Russian-Ukrainian and many other transboundary waters. For detail, See, UNECE, 'The Global Opening of 1992 Water Convention' (New York and Geneva 2017) <https://www.unece.org/fileadmin/DAM/env/water/publications/WAT_The_global_opening_of_the _1992_UNECE_Water_Convention/ECE_MP.WAT_43_Rev1_ENGLISH_WEB.pdf $>$ accessed 16 February 2021.

51 UNECE Convention (n 1) art 2(2)(b) and (d). 
resources management and protection (Article 3). In taking measures to prevent, control and reduce any transboundary impact, including on the environment, the Parties are required to be guided the precautionary principle and polluter-pays principle and the principle of inter-generational equity (Article 2.5). Such details are absent in the 1997 Convention.

Second: the 1997 Convention mentions only the phrase 'Environmental Impact Assessment' as part of the obligations under exchange of information. Conversely, the 1992 Convention details out the environmental assessment requirements and requires exchanging information and data on environmental conditions of transboundary waters and measures taken to prevent, control and reduce transboundary impact (Articles 9, 11 and 13).

Third: the 2000 European Water Directives adopted under the 1992 Convention asks, in line with Article 2(2) (d) of the Convention, for reviewing planned measures every five years and restoring river ecosystems through measures like floodplain restoration and installation for fish migration.

Further, Article 9 of the 1992 Convention obliges the basin states to enter into new agreements or adapt existing watercourse agreements and establish joint bodies for implementing the agreement in line with the basic contents of the Convention, whereas the 1997 Watercourses Convention only recommends watercourse States to do so. The suggested tasks of such joint bodies include collecting, compiling and evaluating data in order to identify pollution sources, elaborating joint monitoring programmes concerning water quality and quantity, evaluating the effectiveness of control programmes, serving as a forum for the exchange of information on existing and planned uses of water and related installations and participating in the implementation of environmental impact assessments.

However, it needs to be noted that these differences in the aforesaid Conventions are more in detail than in core substance. Therefore, the implementation of one Convention would not impede the implementation of the other. ${ }^{52}$ Rather, the complementary nature of these two conventions has been underlined by the the UN Secretary-General at the 6th session of the Meeting of the Parties to the 1992 UNECE Water Convention, where hestated that, "These two instruments are based on the same principles. They complement each other and should be implemented in a coherent manner.' 53

\section{THE 2004 BERLIN RULES}

52 'Fragmentation Of International Law: Difficulties Arising From The Diversification And Expansion Of International Law - Analytical Guide To The Work Of The International Law Commission International Law Commission' (Legal.un.org, 2021) <https://legal.un.org/ilc/guide/1_9.shtml> accessed 16 January 2021.

53 UN, 'The Secretary-General Message to Meeting of the Parties to the United Nations Economic Commission for Europe (UNECE) Convention on the Protection and Use of Transboundary Watercourses and International Lakes' (Rome, 28-30 November 2012) <https://www.unece.org/fileadmin/DAM/env/water/mop_6_Rome/Presentations/Secretary_Ge neral_message.pdf $>$ accessed 6 February 2021.

Page | 142 
The 2004 Berlin Rules represents a revision of the Helsinki Rules formulated by the ILA in 1966.On the basis of analysis of representative international agreements, these Rules integrate traditional rules regarding transboundary waters with rules derived from the customary international environmental law and international human rights law that apply to all waters, national as well as international. ${ }^{54}$ They emphasize more on environmental issues than any other previous codification.

Articles 7 and 8 of the Rules require the States to take all appropriate measures to manage waters sustainably and prevent or minimize environmental harm. The commentary on Article 8 recognizes the importance of other factors in determining equitable utilization, but asserts that environmental harm 'deserves special attention'. Articles 29-31 and Articles 56-67respectively elaborate environmental impact assessment obligations as well as obligations of international cooperation and administration for applying the Article 8 principle.

Berlin Rules put heavy emphasis on establishing a basin wide or joint agency or commission with authority to undertake the integrated management of waters of an international drainage basin to ensure equitable and sustainable use of waters and prevention of harm (Article 64). A basin wide management mechanism requires having adequate authority to establish harmonized, coordinated, or unified networks for permanent observation and control and harmonized water quality objectives. It must have the functional and financial autonomy and a defined legal status (Article 65). The Commentary on Article 64 provides that although customary international law does not specifically require such institutions be established, basin wide management mechanisms are the best or even a necessary means for achieving equitable and sustainable management of waters.

\section{A. Judicial Recognition of Environmental Obligation}

The above codification, in particular the 1997 Convention, has been highly regarded in international legal proceedings. Some of the later judicial decisions provide strong evidence of an increasing focus on the applicability of environmental principles in the use of international watercourses.

Within months of its adoption, the ICJ referred to this Convention in its judgment in the Gabčikovo-Nagymaoscase. ${ }^{55}$ As Philippe Sands and others summarized, ICJ judgment in this case affirmed the importance of environmental considerations in addressing rights and obligation of riparian states in an international watercourse. ${ }^{56}$

Some of the principles of the Conventions have been taken into account in subsequent

54 ILA, 'Berlin Rules on Water Resources Law,' (Berlin Conference 2004) $<$ https://www.unece.org/fileadmin/DAM/env/water/meetings/legal_board/2010/annexes_groundwate r_paper/Annex_IV_Berlin_Rules_on_Water_Resources_ILA.pdf $>$ accessed 16 December 2020.

55 Case Concerning Gabčikovo-Nagymaros Project (Hungary v Slovakia) (Merits) [1997] ICJ Rep 7, Para 85.

56 Philippe Sands, Jacqueline Peel, With Adriana Fabra and Ruth MacKenzie Frontmatter, Principle of International Environmental Law (2 ${ }^{\text {nd }}$ edn, Cambridge University Press 2012) 318. 
cases as well. For example, in 2010, the ICJ in the Pulp Mills on the River Uruguay case recalled that "the existence of the general obligation of States to ensure that activities within their jurisdiction and control respect the environment of other States or of areas beyond national control is now part of the corpus of international law relating to the environment". ${ }^{57}$ Previously, in its interim Order of 13 July 2006, the court underscored the importance of sustainable development and conservation of the river environment. ${ }^{58}$ The Court also reiterated the observation in the GabcikovoNagymaros case: "in the field of environmental protection, vigilance and prevention are required on account of the often irreversible character of damage to the environment and of the limitations inherent in the very mechanism of reparation of this type of damage. $^{59}$

In a more recent case, concerning the status and use of the waters of the Silala River (2016), Chile complained ${ }^{60}$ that Bolivia, the upstream state of the Silala River, had breached the American Treaty on Pacific Settlement of 1948 as well as customary law of equitable utilization and no-harm by undertaking unilateral planned measures. ${ }^{61}$

Bolivia did not deny customary legal obligations associated with the use of the river. Instead, it merely argued that the Silala is not an international watercourse as it had been artificially diverted to Chile long before its own planned measures. Chile, on the other hand, maintained that the Silala River naturally flows towards Chile due to the natural inclination of the terrain. The application of customary rules, in this case, would depend largely on resolving this dispute over the status of the river, but the customary status of the principles remains valid. ${ }^{62}$

The above discussion clearly shows increasing integration of environmental

57 See Pulp Mills on the River Uruguay (n 32) 7.

58 Ibid para 80.

59 Case Concerning Gabčikovo-Nagymaros Project (n 54).

60 see, Dispute over the Status and Use of the Waters of the Silala (Chile v Bolivia) (Application instituting proceeding) (2016) <https://www.icj-cij.org/public/files/case-related/162/162-20160606APP-01-00-EN.pdf> accessed 6 February 2021.

61 As Cullet observed, the application of substantive rules of equitable utilisation and no-harm as well as the procedural rules of cooperation were argued to be applicable as customary rules in view of considering the Silala River as an international watercourse. Philippe Cullet, 'Water Law - Evolving Regulatory Framework' in Philippe Cullet, Alix Gowlland-Gualtieri, Roopa Madhav, and Usha Ramnathan (eds), Water Governance in Motion, Towards Socially and Environmentally Sustainable Water Laws (Foundation Books 2010)27-31. See also, Mihajlo Vučić, 'Silala Basin DisputeImplications for the Interpretation of the Concept of International Watercourse' (2017) LXV:4 Annals FLB - $\quad$ Belgrade $\quad$ Law $\quad$ Review 91 $<$ https://www.researchgate.net/publication/323179435_Silala_basin_dispute_Implications_for_the_i nterpretation_of_the_concept_of_international_watercourse> accessed 16 February 2021; and Roberta Greco, 'The Silala Dispute: Between International Water Law and the Human Right to Water' (2017) 39 QIL 23-37 <http://www.qil-qdi.org/silala-dispute-international-water-law-human-rightwater-forthcoming/> accessed 6 February 2021.

62 On June 21, 2019, The ICJ authorizes the submission by Chile of an additional pleading relating solely to the counter-claims of Bolivia.

Page $\mid 144$ 
obligations with the basic principles of international watercourse law. While analyzing this integration, Owen McIntyre commented that, "[a]t any rate, it is possible to argue that environmental factors are likely to enjoy a certain priority, or at least an increasing significance, within the balancing process that comprises practical implementation of the principle of equitable utilization." ${ }^{63}$

\section{B. South Asian Practices}

The ecology centric approach or ecological focus of the above codifications has noticeable influence on or reflection in subsequent state practice. In addition to the hugely efficient environmental regime established in internationals watercourses in Europe such as those concerning the Danube or Rhine rivers, ${ }^{64}$ agreements with similar provisions are also concluded in less developed areas in Asia and Africa. Examples concerning sustainable development and use of transboundary watercourses in Africa include the Revised SADC Watercourses Protocol of August 2000 and the 1994 Agreement on the preparation of A Tripartite Environmental management program for Lake Victoria. ${ }^{65}$

Among the watercourse agreements in Asia addressing obligation to take account of environmental concerns, one prime example is the 1995 Agreement on co-operation for Sustainable Development of the Mekong River Basin. It aims at fostering cooperation in all fields of sustainable development, utilization, management and conservation of the water and related resources of the Mekong River Basin (Art. 1, Mekong Agreement). It, therefore, requires parties to make every effort to avoid, minimize and mitigate harmful effects to the environment, water quality and quantity and ecological balance of the river system (Art. 7). Further, the agreement established a Mekong River Commission to fulfill the above objectives and over the past years, the Commission has formulated a variety of procedures for complementing and facilitating implementation of the general provisions. These include Procedures for Maintenance of Flows on the Mainstream approved in 2006 and Procedures for Water Quality, approved in $2011 .^{66}$

\section{Existing Watercourse Regimes}

The above recent developments of international watercourse law, however, have very little influence on state practice in South Asia. Among the major agreements in this region, the Indus Water Treaty of 1960 between India and Pakistan has simply

63 Owen McIntyre (n 36) 361.

64 The 1998 Convention on the protection of the Rhine covers aquatic and terrestrial ecosystem which interact with the Rhine and the 1994 Convention on Co-operation for the Protection and sustainable Use of the Danube River provides for protection of the riverine environmental, conservation and restoration of ecosystem and sustainable development of the River. See, Ibid 289.

65 For resources on global influence and relevance of the Convention, see, 'Global Relevance - UN Watercourses Convention' (n 42). See also, Flavia Rocha Loures and AlistarRieu Clarke (n 43).

66 Rémy Kinna and Alistair Rieu-Clarke, 'The Governance Regime of the Mekong River Basin, Can the Global Water Conventions Strengthen the 1995 Mekong Agreement?' (2017) 2(1) Brill Research Perspectives in International Water Law 1-84. 
apportioned the Indus water system between the two states without making reference to or reflecting any environmental obligation. Although the text of the Treaty includes review provisions in Article XII (3), this opportunity has never been taken by the contracting parties for updating it in accordance with the developing environment norms of international watercourse law.

This Treaty however has stronger procedural obligations like third party dispute settlement which has succeeded in resolving disputes on the interpretation of the treaty in a number of occasions. But such interpretation, as well, had largely avoided reflecting on the development of related environmental norms due to disagreement of the Parties on this issue.

For Example, in a recent dispute concerning the Kishenganga dam project undertaken by India at the upstream of the Indus, India opposed Pakistan's argument for interpreting the 1960 Indus Treaty in the light of present state of international watercourse law and transboundary environmental obligations. International tribunals have, on a number of occasions, underscored the necessity of employing such evolutionary approach in interpreting earlier treaties. ${ }^{67}$ But this could hardly be done in this case due to the opposing view of the concerned state parties.

In the Kishenganga case, as Musa observed, Pakistan referred to Iron Rhine arbitration, the ICJ's decisions in Gabcikovo-Nagymaros, and Pulp Mills to argue that determination of the material damage to be caused by diversion of the Kishenganga/Neelum from its natural channels should include ecological harm. India, on the other hand, argued that its project was in conformity with the Indus Treaty and the treaty should be interpreted according to its ordinary meaning which did not permit importing principles of environmental harm in elaborating its content. Consequently, the tribunal avoided addressing whether environmental harm constituted material damage. ${ }^{68}$

The tribunal, in its Final Award of 2014, refused to accept that environmental considerations could override the balance of rights and obligations enshrined in the Indus Treaty. As Musa concludes, while fixing the structure and capacity of the India's project, it did reflect some notions of environmental harm, but only to the extent established as customary international law. ${ }^{69}$

India's general reluctance to interpret treaties in the light of development of IEL could also be inferred from its strong objection against the relevant provisions of the 1997 Watercourse Convention. During the UNGA Sixth Committee Working Group negotiation for adoption of the Convention, India observed that Article 3 of the convention failed to reflect the right of the States to conclude international watercourse

67 Such evolutionary or dynamic treaty interpretation was applied by the Arbitral Tribunal in the Iron Rhine case and by the ICJ in the Gabcíkovo-Nagymaros case. See, Jasmine Moussa, 'Implications of the Indus Water Kishenganga Arbitration for the International Law of Watercourse and the Environment' (2015) 64 International and Comparative Law Quarterly 714.

69 Ibid 713

Page | 146 
agreements without being fettered by the present Convention, ${ }^{\text {, }}$ and objected to the 'superimposition of the concept of sustainable development' on the principle of optimum utilization in Article 5 . $^{71}$

Among the other watercourse treaties in the South Asia, the older agreements between India and Nepal on the Kosi and Gandak Rivers did not have any provision concerning environmental obligations of the state parties. ${ }^{72}$ The 1996 Mahakali River Treaty between India and Nepal is the only one which in part addresses environmental issues. Article 1(2) of the Treaty requires India to ensure a minimum flow of 350 cusecs downstream of the Sarada Barrage in order to maintain and preserve the river ecosystem. ${ }^{73}$ This Treaty has, however, hardly been implemented because of strong disputes between the State Parties concerning the interpretation of its various provisions. ${ }^{74}$

The Bangladesh-India treaty relations appear to be even worse. Bangladesh is a downstream country of 57 international rivers, 54 among them are flowing from India after originating from various sources. Among them, Bangladesh and India have entered into treaty relations in respect of only one international river although a joint river commission between them was established as early as 1972. That treaty was concluded for sharing of the Ganges for a period of 30 years commencing from 1996.

This treaty basically provides for sharing of the Ganges flow for meeting various needs of Bangladesh and the requirement of the Farakka project constructed in the 1970s for

70 See Attila Tanzi, 'Codifying the minimum standards of the law of international watercourses' (1997) 21 NRF 111. Tanzi noted that during the Sixth Committee Working Group meetings, India was one of the States (others were Argentina, Egypt, France, Pakistan, Switzerland and USA) who proposed that a specific provision should be inserted that the rights and obligations arising from existing agreements should not be affected by the Convention. According to Nussbaum, such proposal was also made by Italy, Turkey, Canada and Romania. See Nussbaum(n 16).

71 As its delegate explained the reasons: "international environmental regimes contain certain elements such as transfer of technology, resources and technical expertise to promote capacity-buildings among developing countries. None of these elements is elaborated in the present Convention". See,UNGA Res 51/229(n 1) 9.

72 Agreement between the Government of India and the Government of Nepal on the Kosi Project (25 April 1954) (1963) UNLegislative Series 290; See also, Agreement between the Government of India and the Government of Nepal on the Gandak Irrigation and Power Project (4 December 1959) (1963) UN Legislative series 295.

73 The Treaty between His Majesty's Government of Nepal and the Government of India Concerning the Integrated Development of the Mahakali River Including Sarada Barrage, Tanakpur Barrage and Pancheshwar Project (New Delhi, 12 February 1996) 36 ILM 531 <https://docs.pcacpa.org/2016/01/Treaty-Between-His-Majesty\%E2\%80\%99s-Government-of-Nepal-and-the-

Government-of-India-Feb.-12-1996-36-I.L.M.-531.-1.pdf> accessed 16 February 2021.

74 For an overview of India-Nepal Relation in regard to utilization of shared rivers, see Salman M. A. Salman and Kishor Uprety, Conflict and Cooperation on South Asia's International Rivers: A Legal Perspective (Washington DC: World Bank Group 2003) 65-125 <http://documents1.worldbank.org/curated/en/249581468325224527/pdf/multi0page.pdf> accessed 16 February 2021. For very recent analysis of the deadlock concerning the Mahakali Treaty, see Nabraj Lama, 'Re-negotiating the Mahakali Treaty in the changing geopolitics of Nepal' (2019) 9(1) International Journal of Scientific and Research Publications $417<$ http://www.ijsrp.org/researchpaper-0119/ijsrp-p8554.pdf> accessed 16 February 2021. 
diverting the Ganges flow to rejuvenate Calcutta Port in West Bengal of India. However, it has disregarded the impact of Indian projects in the further upstream areas of the Ganges, such as those in Bihar and Uttar Pradesh ${ }^{75}$ on water availability at Farakka, a place near Bangladesh-India border and the agreed point of allocation of downstream Ganges flows between Bangladesh and the Calcutta Port of India. ${ }^{76}$ Consequently, the actual water availability was found to be less than the stipulated figures on many occasions during the driest period from mid-March to mid-May. ${ }^{77}$ The Treaty, has, thus, failed to protect the downstream Bangladesh from economic and environmental harm. ${ }^{78}$

Further, the 1996 Treaty is silent on substantive rules on protecting the environmental flow and river-based ecosystem, prevention and control of pollution. It also ignores procedural obligations on environmental impact assessment, third-party dispute settlement and harmonization of water policies.

\section{THE 1996 GANGES TREATY IN THE LIGHT OF THE 1997 CONVENTION}

The 1996 Ganges Treaty will expire in 2026. A brief comparison between this treaty and 1997 Watercourse Convention is outlined below for indicating the areas, which any future negotiation between these countries should take into account.

First, the 1997 Convention provides for taking all appropriate measures to prevent causing of significant harm to other watercourse States (Article 7). Further, the Convention, by elaborating the post-harm obligation, has established a firm relation between equitable utilization and harm factor, which is not done in the 1996 Ganges Treaty. The 1996 Treaty does not oblige its Parties to take any preventive measures. It

75 In a 1972 debate on Farakka Barrage in the Indian Parliament, the Ministry of Irrigation and Power asserted that Indian Government would 'fully' safeguard the interest of the irrigation projects in upstream states of India. A World Bank study warned that these upstream projects could divert $40 \%$ of the dry season flow of the Ganges. See, Md Nazrul Islam, 'Equitable Sharing of the Water of the Ganges, Applicable Procedural Rules under International Law and Their Adequacy' (unpublished PhD thesis, SOAS- University of London 1999) 66. Complaint about withdrawal by hundreds of upstream projects was raised in Indian Media as well. See, for example, 'Indo-Bangla Accord, Defying the current' India Today (India, 15 January 1997) 110-11.

76 The Ganges water dispute originated from the unilateral construction by India of the Farakka Barrage during the 1960s to divert the Ganges dry season flow to the Hooghly-Bhagirathi River to rejuvenate its Calcutta Port. See, Ben Crow et al., Sharing the Ganges, The Politics and technology of river development (Dhaka: UPL 1995) 26-75.

77 Kimberley Thomas, 'The Ganges water treaty: 20 years of cooperation, on India's terms' (2017) 19 Water Policy 724-740 <https://www.researchgate.net/publication/315119940_The_Ganges_water_treaty_20_years_of_coo peration_on_India's_terms> accessed 6 February 2021.

78 Bangladesh received less water in crucial periods and raised question about unlimited upstream diversion and later also about the projects India was planning to undertake in the tributaries of the Ganges with Nepal. see, 'Record Of The Discussion Of The Thirty Fifth Meeting Of The IndoBangladesh Joint River Commissions Held at Delhi On 29th and 30th September 2003' (Waterbeyondborders.net,

<http://waterbeyondborders.net/files/minutes_of_meeting/Ind_ban_JRC_35_sep2003.pdf> accessed 6 February 2021. Similar statement was made in the $36^{\text {th }}$ meeting in 2005.

Page $\mid 148$ 
also fails to spell out that unlimited upstream diversion of the Ganges water is not compatible with ensuring adequate protection of the river which is an essential component of equitable utilization as explained in the 1997 Convention.

Second, the Convention requires exchange of all relevant information on watercourse conditions (Article 9), and planned measures (Article 11) as well as technical data and information including the result of any EIA (Article 12). It also provides for adequate consultation between the watercourse states (Article 17). A comprehensive application of these provisions would, therefore, require India to consult Bangladesh regarding all the upstream projects on the river Ganges including those with Nepal. Regrettably, under Articles I, II, and IV, the 1996 Treaty provides for exchange of information available only at and down the Farakka point and for consultations apparently on the basis of such information.

The 1996 Treaty appears to have taken into account only the economic aspects of the Farakka project, not the environmental impact of that or other upstream projects. It is also silent on pollution issues so emphatically addressed in the global codifications and judicial decisions discussed earlier.

\section{CONCLUDING REMARKS}

Although none of the South Asian countries have so far ratified or acceded to the 1997 Watercourse Convention, they may have an obligation of complying with the customary rules of international watercourse codified in the Convention. This is because none of them is persistent objector to any of the substantive or procedural principles emerged or established during the negotiation of the 1996 Treaty or thereafter. For example, although India objected to third party dispute settlement during the negotiation of the 1997 Convention, it previously concluded agreements with both Pakistan (in regard to Indus Treaty) and Nepal (in regard to Mahakali Treaty) which provide for third party dispute settlement.

India's (and to some extent Bangladesh's) objections to other issues basically centre on the relationship between equitable sharing and no-harm principles. The procedural principles for addressing this and environmental issues have not been objected by India or Bangladesh during the elaboration of the 1997 Convention. These principles require negotiation in good faith, rejection of unilateral measures and equitable adjustment of all uses. Full compliance with such principles would ensure utilization of a shared watercourse in a way which would more efficiently ensure the interest of the basin states of an international watercourse.

India did object to the superimposition of the environmental issue in the definition of equitable utilization, but that alone cannot qualify it as persistent objector to environmental obligation. India along with all other states of South Asia are party to important environmental agreements such as 1992 convention on Biodiversity, and 2015 Paris Agreement on Climate change which require them to take account of environmental aspects of use and management of natural resources including 
international watercourses. ${ }^{79}$ When faced with the prospect of adverse impact of China's plan for constricting a gigantic dam on the upstream of the Brahmaputra river, India also raised question about the legality of this move. ${ }^{80}$

The above analysis suggests that Bangladesh and India (and other states of South Asia in general), for their long-term benefits, need to have a wider vision to establish a basinwide management for sustainable development and utilization of the transboundary water resource. They need to understand that equitable utilization or no-harm principles cannot be translated into reality without taking account of the environmental function of the watercourse. In doing that, they should respect and embrace both established and emerging customary rules reflected in the 1997 Convention and other relevant instruments.

This could always be done by modifying the existing regime which lacks in reflecting contemporary or later developed environmental norms. As McCaffrey commented on the observation of the ICJ in the Gabčíkovo-Nagymaros Project case on related issues, the Court recognizes an environmental imperative as so powerful that it requires the new norms and standards be taken into account and given proper weight even when states are "continuing with activities begun in the past." Otherwise, economic development would not be sustainable. ${ }^{81}$

Bangladesh and India could have modified the 1996 Treaty by paying due regards to the contemporary development of international watercourse law during review of the Ganges Treaty. They still have the scope of doing this both in future negotiations for extension of the Ganges Treaty after its expiration in 2026 and for concluding agreements in regard to the utilization of other common rivers. Such opportunities are available for other South-Asian States as well.

\footnotetext{
79 Md Nazrul Islam (n 44).

${ }^{80}$ For updates on this issue, <https://timesofindia.indiatimes.com/india/india-plans-dam-onbrahmaputra-to-offset-chinese-construction-upstream/articleshow/79510971.cms $>$ accessed on December 1, 2021

81 Stephen C. McCaffrey (n 19) 508.

Page | 150
} 
Environmental Obligations in International Watercourse Law and South Asian Practice 